\title{
An Overview of REBA Method Applications in the World
}

\author{
Manuel Hita-Gutiérrez ${ }^{1}$, Marta Gómez-Galán ${ }^{1}$, Manuel Díaz-Pérez ${ }^{1}$ (D) and \\ Ángel-Jesús Callejón-Ferre ${ }^{1,2, *(D)}$ \\ 1 Department of Engineering, University of Almería, Research Center CIMEDES (CeiA3), \\ 04120 Almería, Spain; manuelhitagutierrez@gmail.com (M.H.-G.); mgg492@ual.es (M.G.-G.); \\ madiaz@ual.es (M.D.-P.) \\ 2 Laboratory-Observatory Andalusian Working Conditions in the Agricultural Sector (LASA), \\ 41092 Seville, Spain \\ * Correspondence: acallejo@ual.es; Tel.: +34-950-214-236; Fax: +34-950-015-491
}

Received: 11 February 2020; Accepted: 8 April 2020; Published: 12 April 2020

\begin{abstract}
The objective of this work is to review literature, worldwide, in which the Rapid Entire Body Assessment (REBA) ergonomic assessment method was applied and count the number of times that REBA was applied together with other methods and subsequent incidence. The database used was the "Web of Science-Core Collection". Only scientific articles and bibliographic reviews were included, analysing a total of 314 documents and selecting only 91. The use of the REBA method is indicated in terms of knowledge, country, year and journal sectors. It was most used in the knowledge areas of "Manufacturing" (24.18\%), "Agriculture, forestry and fishing" (21.98\%) and in "Other activities" (19.78\%). One of the benefits of REBA is that it evaluates different body parts: upper limbs (arm, forearm and wrist), lower extremities, trunk and neck. It is a useful method to identify the forced postures adopted by workers to thus develop improvement measures if necessary. It is concluded that REBA method use has increased over the last decade, probably due to the digitization of knowledge. It is almost always applied in combination with other methods, and its use can be a positive indicator of company sustainability.
\end{abstract}

Keywords: musculoskeletal disorders; safety and health; biomechanics; physical load

\section{Introduction}

\subsection{Musculoskeletal Disorders}

According to the International Ergonomics Association [1], "ergonomics (or human factors) is the scientific discipline concerned with the understanding of interactions among humans and other elements of a system, and the profession that applies theory, principles, data, and methods to design in order to optimize human well-being and overall system performance".

The World Health Organization (WHO) states that Musculoskeletal Disorders (MSD) "range from those that arise suddenly and are short-lived, such as fractures, sprains and strains, to lifelong conditions associated with ongoing pain and disability". These disorders occur in people of any age and in all parts of the world. This disease has important economic consequences and implies a decrease in job performance, in addition to affecting the health of people who suffer from them [2].

The National Institute for Occupational Safety and Health (NIOSH) [3] defines musculoskeletal disorders as "a set of injuries and symptoms affecting the osteomuscular system and associated structures, such as bones, muscles, joints, tendons, ligaments, nerves and the circulatory system". 
To combat MSDs, ergonomic assessment methods are used to identify and assess the risk factors present in the workplace, and then, based on the results obtained, to propose redesign options that reduce the risk to acceptable exposure levels for the worker [4].

Currently, given that applying ergonomic methods is sometimes tedious because of the number of aspects to consider, software exists that makes it much easier, in terms of time and efficiency, to obtain the final results [5].

\subsection{Assessment Methods}

The methods used for evaluating musculoskeletal disorders vary depending on the country, the companies carrying them out and the working environment, etc. For this reason, it is possible to classify them as direct, semi-direct or indirect methods [5]. Direct methods require electronic devices to be placed on the individual's body, evaluating the worker in real time. Semi-direct methods (Figure 1) are based on images that are subsequently evaluated while indirect methods use questionnaires.

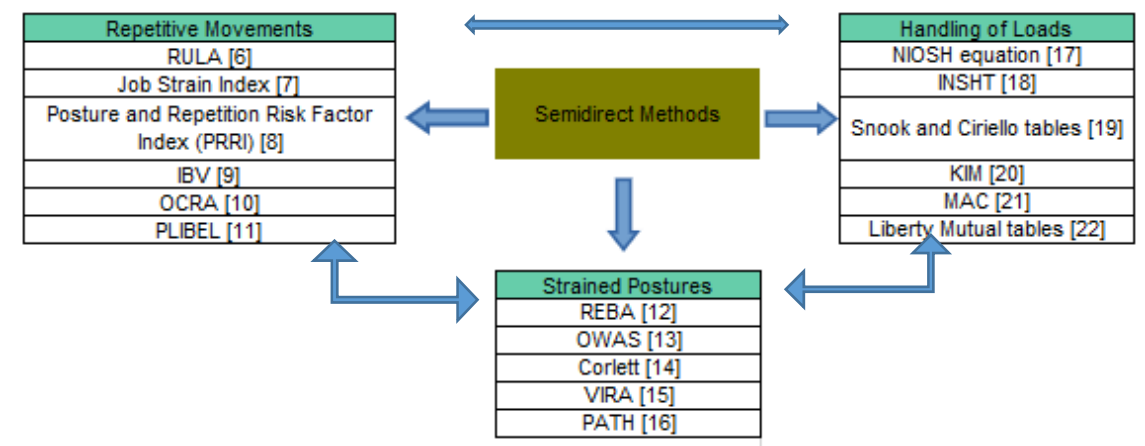

Figure 1. Semi-direct methods according to the cause of the musculoskeletal disorders and their combined use (adapted from Reference [5]). Rapid Upper Limb Assessment (RULA) [6]; Job Strain Index (JSI) [7]; Posture and Repetition Risk Factor Index (PRRI) [8]; Instituto de Biomecánica de Valencia (In Spanish; IBV) [9]; Occupational Repetitive Action (OCRA) [10]; Method for the identification of musculoskeletal stress factors which may have injurious effects (PLIBEL) [11]; Rapid Entire Body Assessment (REBA) [12]; Ovako Working Analysis System (OWAS) [13]; Corlett [14]; Video film technique for Registration and Analysis of working postures and movements (VIRA) [15]; Posture, Activity, Tools and Handling (PATH) [16]; National Institute of Occupational Safety and Health (NIOSH) [17]; Instituto Nacional de Seguridad e Higiene en el Trabajo (In Spanish; INSHT) [18]; Snook and Ciriello tables [19]; Key Indicator Method (KIM) [20]; Manual Handling Assessment Charts (MAC) [21]; Liberty Mutual tables [22].

Semi-direct methods can be classified according to the cause of the MSD. In this study, the Rapid Entire Body Assessment (REBA) method is one of the methods used for assessing forced postures (Figure 1).

The application of methods such as REBA has evolved over time. It started with photographs, paper and pen. Over time, progress was made using video recordings and employing analysis of this through software. Currently, some equipment is used to measure angles and evaluate in real time [23,24].

\subsection{The Rapid Entire Body Assessment Method (REBA), Justification and Objective}

This method was developed by Sue Hignett and Lynn McAtamney at Nottingham Hospital (The United Kingdom) and published in 2000 [12]. It is the result of cooperative work carried out by teams of ergonomists, physiotherapists and nurses after identifying/analysing around 600 working postures. REBA allows one to jointly analyse the postures of the upper limbs (arm, forearm, wrist), trunk, neck and lower extremities. In addition, it discriminates the type of grip and muscle activity performed. It identifies five levels of risk, from negligible to very high [12]. 
The main advantages of the REBA method are [25]:

a. The cost-effectiveness ratio is good.

b. It is easy to apply. Pen and paper are enough for data collection; however, there are computer applications that speed up/facilitate its use.

c. The most conflictive ergonomic aspects are identified from the individual score obtained after assessing each part of the body.

The main limitations are [25]:

a. It only allows the analysis of individual postures. It is not possible to analyse a set or sequence of postures.

b. Task evaluations will depend on the evaluator. Some of the positions adopted may or may not be examined.

c. It only measures the effort intensity. The duration of exposure and the frequency of postures throughout the working day are not considered.

One of the requirements of the method is to have the consent of the worker to obtain the necessary information. The evaluators observe all the tasks to be analysed. Observation can be completed in three ways: direct observation, video recording or taking photographs. The aim is to collect data that allows the method to be used to obtain results.

On the other hand, the method presents some differences with respect to others. One of the main differences is that it considers the lower extremities of the worker [12]. These are not considered by other evaluation methods such as RULA [6]. There are no better or worse methods, but they are applied depending on the evaluators' situations and resources [26].

It should be noted that once the method has been published, over the years, it is very important to know its worldwide application.

Examining the use of the REBA method, since its inception, would justify the impact of this method on society.

The main objective of this work is to carry out a bibliographic review of the REBA method [12] application in the fields of knowledge, countries, years and journals from the period May 2002 to July 2019. In addition, this study aims to count the number of times that REBA has been applied together with other methods and subsequent incidence. Finally, an objective is to demonstrate whether it has been applied in the health field and what happens with respect to the rest of the knowledge categories.

\section{Materials and Methods}

\subsection{Searching for Information}

In order to search for the information, electronic access to the library of the University of Almeria was used. Then the "Web of Science-Core Collection (WOS)" database was accessed. Its license is granted by Spanish Foundation for Science and Technology (FECYT).

It was assumed that all the researchers who applied REBA in any field of knowledge would have cited the article where this method was published. Therefore, the search process was performed to access all the studies that cited it. "Advanced Search" was used in WOS with the terms "so=applied ergonomics and $\mathrm{t} i=$ Rapid entire body assessment (REBA)". In this way, a single result was obtained, which was the original article of REBA [12]. Accessing this result, the "Times Cited" section was consulted, which showed all the studies that had cited the REBA article [12]. There was a total of 442, in the period from 2002 to $10 / 07 / 2019$.

Of the 442 citations, books, book chapters or other formats were discarded, finally obtaining 314 citations for articles and reviews. It is worth reiterating that only the WOS database was used.

Of these 314 results, the number of studies finally selected for this document was 91 . These do not include the original article of the method. Some studies were discarded because they were repeated 
articles, sometimes as reprints or as conferences that were subsequently published in journals, so only the original article was considered. Others were discarded because, although they cited the paper on the REBA method, they did not apply it in the research. Only articles using REBA method were considered, individually or in combination with other methods.

\subsection{Data Analysis}

Variables, categories and their abbreviations are shown below (Table 1). In addition, all journals were considered.

Table 1. Variables, categories, and abbreviation.

\begin{tabular}{|c|c|c|}
\hline Variable & Categories & Abbreviation \\
\hline \multirow{10}{*}{ Sector } & Agriculture, forestry and fishing & A \\
\hline & Manufacturing & $\mathrm{C}$ \\
\hline & Transportation and storage & $\mathrm{H}$ \\
\hline & Water supply; sewerage, waste management and remediation activities & $\mathrm{E}$ \\
\hline & Professional, scientific and technical activities & M \\
\hline & $\begin{array}{l}\text { Activities of households as employers; undifferentiated goods-and } \\
\text { services-producing activities of households for own use }\end{array}$ & $\mathrm{T}$ \\
\hline & Construction & $\mathrm{F}$ \\
\hline & Education & $\mathrm{P}$ \\
\hline & Human health and social work activities & $\mathrm{Q}$ \\
\hline & Other activities & OTH \\
\hline \multirow{5}{*}{ Year } & Items between 2006 or before & Y1 \\
\hline & Items between 2007 and 2010 & $\mathrm{Y} 2$ \\
\hline & Items between 2011 and 2013 & Y3 \\
\hline & Items between 2014 and 2016 & Y4 \\
\hline & Items between 2017 and 2019 & Y5 \\
\hline \multirow{4}{*}{ Country } & $\begin{array}{l}\text { Europe: United Kingdom, Sweden, Poland, Croatia, Italy, Germany, Portugal and } \\
\text { Spain }\end{array}$ & $\mathrm{C} 1$ \\
\hline & Asia: Israel, Iran, India, South Korea, China, Singapore, Malaysia and Turkey & $\mathrm{C} 2$ \\
\hline & America: USA, Mexico, Brazil, Canada, Venezuela and Cuba & C3 \\
\hline & Africa: Tunisia and Nigeria & $\mathrm{C} 4$ \\
\hline Journal & - & - \\
\hline
\end{tabular}

The knowledge categories, countries and years were grouped to facilitate data management. Countries were grouped into continents. Not all countries on a continent are shown, only those where the REBA method was applied.

On the other hand, the 91 final studies were grouped according to field, year, country and journal. For the general grouping by sectors, an adapted classification was used [27]. Another classification was made within each sector, but in this case it was from the information obtained from studies analysed, for greater clarity and organization of this information.

XLSTAT2019 (Addinsoft, Paris, France) [28] software was used for the results analysis.

\section{Results and Discussion}

The frequencies of each variable category are shown in Table 2.

The area in which the method was applied most is the "Manufacturing (C)" followed by "Agriculture, forestry and fishing (A)" and "Other activities (OTH)". Between the period 2014 and 2019 (Y5 and Y4), more than 70\% of the REBA applications were published. Half of the studies with REBA were published in Asia (C2). The total number of journals is 91. The most striking observation is that, although the method was initially published in 2000, its application was not significant until about 15 years later, possibly because of the digitization of academic/scientific content and the massive user access via the internet [29]. This coincides with other applications concerning ergonomic assessment methods, namely the case of OWAS [5].

Risk assessment is mandatory in all companies. Each one chooses the evaluation method. REBA [12] allows for the identification of the musculoskeletal disorders suffered by workers in different fields, mainly forced postures. 
Table 2. Category frequencies.

\begin{tabular}{cccc}
\hline Variable & Category & Frequency & $\%$ \\
\hline \multirow{5}{*}{ Sector } & A & 20 & 21.98 \\
& C & $22^{*}$ & 24.18 \\
& E & 2 & 2.20 \\
& F & 4 & 4.40 \\
& H & 4 & 4.40 \\
& M & 2 & 2.20 \\
& OTH & 18 & 19.78 \\
& P & 1 & 1.10 \\
Q & 15 & 16.48 \\
& T & 3 & 3.30 \\
\hline \multirow{5}{*}{ Year } & Y1 & 1 & 1.10 \\
& Y2 & 8 & 8.79 \\
& Y3 & 18 & 19.78 \\
& Y4 & 30 & 32.97 \\
& Y5 & $34 *$ & 37.36 \\
\hline Country & C1 & 17 & 18.68 \\
& C2 & $46 * 5$ & 50.55 \\
& C3 & 26 & 2.57 \\
\hline Journal & C4 & 2 & 100 \\
\hline & - & 91 &
\end{tabular}

\subsection{Analysis by Field and Knowledge Categories}

\subsubsection{Human Health and Social Work Activities}

Table 3 shows studies related to human health and social work activities.

Table 3. Human health and social work activities.

\begin{tabular}{ccll}
\hline Reference & Country & Year & \multicolumn{1}{c}{ Objective } \\
\hline$[30]$ & Iran & 2016 & REBA with SPSS in the ergonomic assessment of operating room nurses. \\
{$[31]$} & Poland & 2015 & Combination of ergonomic assessment methods on nursing and surgery personnel. \\
{$[32]$} & Portugal & 2015 & REBA on home-care nurses. \\
{$[33]$} & Germany & 2015 & REBA in comparing GlideScope and Macintosh in the tracheal intubation process. \\
{$[34]$} & United Kingdom & 2017 & REBA in the gynaecological field. \\
{$[35]$} & USA & 2006 & REBA for creating a hospital task scoring algorithm \\
{$[36]$} & South Korea & 2019 & REBA on dental hygienists. \\
{$[37]$} & South Korea & 2014 & REBA on radiologists. \\
{$[38]$} & South Korea & 2013 & REBA on dental hygienists. \\
{$[39]$} & Canada & 2008 & Readapting plans to help overcome bad practice in work activities. \\
{$[40]$} & Iran & 2013 & REBA and NMQ (Standardised Nordic questionnaires for the analysis of \\
{$[41]$} & musculoskeletal symptoms) on the ergonomic assessment of dentists. \\
{$[42]$} & Psrael & 2016 & REBA, NMQ and Karasek on the ergonomic assessment of nurses in hospitals. \\
{$[43]$} & Cuba & 2017 & REBA on nurses. \\
{$[44]$} & 2012 & REBA and NIOSH for the refitting of a vaccine production centre. \\
\hline
\end{tabular}

Hospitals

The REBA assessment method is sometimes combined with results support software, as was the case with Abdollahzade et al. [30] using SPSS in the study of 147 high-risk nurses in Tabriz, Iran. It is also common to create computer applications based on the REBA method. Janowitz et al. [35] created a hospital task-scoring algorithm while several authors [31] established a computer system based on information and communication technologies to support hospital processes.

In 2014, Kim and Roh [37] conducted a REBA method-based study on radiologists with more than five years of experience, demonstrating that MSDs occur mainly in the shoulder and lumbar regions, the same symptoms suffered by surgical nurses in a Portuguese hospital [42].

The combination of ergonomic methods developed by Ratzon et al. [41] in the study of 31 nurses, was not enough to determine the effect of poor postural habits on the job. Therefore, they recommend a longer period of study to see if the intervention might reduce MSDs. 


\section{Dentistry}

Applying REBA to dental hygienists is a common practice in the study of plantar pressure [36] and in the taking of oral X-ray images [38]. On other occasions, it is combined with other methods, as was the case with Rafeemanesh et al. [40] in order to demonstrate that the neck area is the most vulnerable part for these professionals and to raise awareness of the importance of workplace design and rest periods during the activity as a basic prevention principle.

Gynaecology

Several authors [34] observed the need for engineering solutions that allow surgeons flexibility during their interaction with patients.

Otorhinolaryngology (ENT)

A study was carried out to evaluate the musculoskeletal disorders of ENT specialists in the surgical context. Their training and the ergonomic tools used were also analysed. The results show that only $24 \%$ of the workers were trained in ergonomics. It was also concluded that the workers adopted forced postures [44].

\section{Others}

According to Carneiro et al. [32], home-care nurses generally have a moderate postural assessment in their work activities.

When comparing different forms of tracheal intubation, several authors [33] used the REBA method to determine which technique, GlideScope or Macintosh, was less likely to cause musculoskeletal injuries during use, the former scoring the highest and therefore being the one chosen.

In the refitting of a vaccine production centre, Torres and Vina [43], in a study using REBA and $\mathrm{NIOSH}$, established shelf redesigns and working method modifications as a measure to reduce the MSD risk level. On the other hand, Pascal and Naqvi [39] in a Canadian study outlined the need for retraining plans to help raise awareness of the risks posed by bad work activity practices.

\subsubsection{Agriculture, Forestry and Fishing}

Table 4 shows the studies related to agriculture, forestry and fishing.

Table 4. Agriculture, forestry and fishing.

\begin{tabular}{cccl}
\hline Reference & Country & Year & \\
\hline$[45]$ & Brazil & 2015 & REBA in the collection of ornamental plants. \\
{$[46]$} & Italy & 2019 & RULA and REBA on wood chippers in the forestry sector. \\
{$[47]$} & India & 2015 & REBA on potato growers. \\
{$[48]$} & India & 2012 & NMQ and REBA on seed collectors. \\
{$[49]$} & India & 2013 & NMQ, REBA and OWAS in the ergonomic assessment of child potato growers. \\
{$[50]$} & Brazil & 2018 & REBA in livestock activities. \\
{$[51]$} & Malaysia & 2016 & NMQ and REBA in oil palm plantations. \\
{$[52]$} & Turkey & 2019 & OWAS and REBA in wood harvesting in the forestry sector. \\
{$[53]$} & Iran & 2018 & NMQ and REBA in apple harvesting. \\
{$[54]$} & Canada & 2007 & Five ergonomic assessment methods in sawmill installations in the forestry sector. \\
{$[55]$} & Canada & 2008 & Five ergonomic assessment methods in sawmill installations in the forestry sector. \\
{$[56]$} & USA & 2010 & Five ergonomic assessment methods in sawmill installations in the forestry sector. \\
{$[57]$} & Croatia & 2019 & ErgoFellow, REBA and OWAS in the ergonomic assessment of forestry machinery use. \\
{$[58]$} & India & 2018 & Four ergonomic assessment methods in rice cultivation by women. \\
{$[59]$} & Israel & 2016 & REBA on special greenhouse crops. \\
{$[60]$} & Brazil & 2017 & REBA in the ergonomic assessment of forestry machinery. \\
{$[61]$} & USA & 2014 & REBA on tomato cultivation. \\
{$[62]$} & Iran & 2017 & REBA on dairy production. \\
{$[63]$} & Turkey & 2017 & Various ergonomic methods on forest nursery workers. \\
{$[64]$} & Italy & 2013 & Four ergonomic methods in the ergonomic study of forestry machinery use. \\
\hline
\end{tabular}


Forestry

In this sector, REBA began to develop in Canada and the US with the combination of five ergonomic assessment methods in sawmill facilities [54-56]. In addition, ErgoFellow software combined REBA and OWAS methods in the ergonomic assessment of forestry machinery use [57], concluding that chainsaw operator work is more demanding and riskier than that of wood collector operators over the course of the activity [52]. The same conclusions were drawn in the study on chainsaw use employing the OCRA, OWAS, RNLE equation and REBA methods [64]. In 2019, REBA and RULA were compared in wood chipping activity concluding that the latter offered greater risk prevention when applying the method [46]. Likewise, in 2017, several authors [60] used REBA to assess management worker tasks.

In forest nurseries, Unver-Okan et al. [63] combined several ergonomic methods to study working postures, such as seed sifting or machine sowing. They finally chose the RULA method for assessment because of its increased sensitivity in the final result.

Livestock

In the livestock field, Taghavi and Mokarami [62] used the REBA method to assess the postural burden related to feeding, milking and dung removal during milk production. In Brazil, numerous authors [50] did the same with regard to milking and livestock management activities, demonstrating a high level of risk over the course of the activity.

Agriculture

Das and Gangopadhyay [47] applied REBA in potato growers in order to assess musculoskeletal disorders. They showed that one of the most affected body areas was the lumbar region. The same was stated by Das et al. [49] who applied it in the same crop type, but in this case studying children. The method has also been used in the study of crops such as tomato [59,61], pepper [59], rice [58], oil palm [51] and apples [53], as well as in the collection of ornamental plants [45] and seeds [48].

\subsubsection{Manufacturing}

Table 5 lists studies that used the REBA method in different areas of manufacturing.

Table 5. Manufacturing.

\begin{tabular}{|c|c|c|c|}
\hline Reference & Country & Year & Objective \\
\hline [65] & Nigeria & 2016 & REBA and NMQ on beverage bottlers. \\
\hline$[66]$ & Tunisia & 2018 & REBA and RULA in milling, turning and drilling operations. \\
\hline$[67]$ & Turkey & 2015 & REBA and BREBA in the metallurgical sector. \\
\hline [68] & Iran & 2016 & REBA in mineral packers. \\
\hline [69] & Venezuela & 2012 & REBA and OCRA in electric motor assembly. \\
\hline [70] & Turkey & 2017 & $\begin{array}{l}\text { Ergonomic comparison between the Kinect sensor and } \\
\text { electrogoniometer to assess posture. }\end{array}$ \\
\hline [71] & Spain & 2013 & REBA and RULA in the metallurgical sector \\
\hline [72] & Turkey & 2018 & $\begin{array}{l}\text { Creation of an ergonomic assessment questionnaire at Cornell } \\
\text { University for the manufacture of harnesses. }\end{array}$ \\
\hline [73] & Sweden & 2018 & REBA in manual collection operations. \\
\hline [74] & United Kingdom & 2016 & Research on work practices. \\
\hline [75] & Turkey & 2018 & Ergonomic methods in the textile industry. \\
\hline [76] & South Korea & 2007 & OWAS, RULA and REBA in the metallurgical sector. \\
\hline [77] & Mexico & 2015 & REBA in computer repair. \\
\hline [78] & India & 2017 & REBA in sand dredging in Karnataka. \\
\hline [79] & India & 2019 & Ergonomic methods in the Sri Lankan textile industry. \\
\hline [80] & India & 2013 & $\begin{array}{l}\text { RULA and REBA in operations carried out by potters and } \\
\text { sculptors. }\end{array}$ \\
\hline [81] & India & 2018 & REBA in brick kiln workers in Rajasthan. \\
\hline [82] & Iran & 2017 & REBA and NMQ in the rubber industry. \\
\hline [83] & India & 2015 & $\begin{array}{l}\text { Ergonomic methods in the plastic furniture manufacturing } \\
\text { industry. }\end{array}$ \\
\hline [84] & South Korea & 2016 & REBA on automotive assembly lines. \\
\hline [85] & Poland & 2014 & REBA in the packaging industry. \\
\hline [86] & Iran & 2012 & REBA in an electrical products factory. \\
\hline
\end{tabular}


Metallurgical Sector

The first analyses appeared in 2013 in Spain with REBA combined with RULA [71], and with BREBA [67] in 2015 in Turkey, the common goal being to eliminate economic risks and improve the production systems in factories. In the first case, this was achieved by means of simulations and, in the second, by means of photographs. Subsequently, several authors again combined methods (OWAS, RULA and REBA) $[66,76]$ in iron and steel operations that involved milling, turning and drilling.

Textiles

Isler et al. [75] studied 65 operators from different departments (cutting, sewing, ironing, quality control, etc.) in eight companies using video cameras, resulting in a REBA score of more than 11 points; thus, they recommended immediate intervention. In Sri Lanka, 552 female foot-sewing-machine operators were tested, with the medium-high REBA intervention warning regarding problems in the knees, feet and thighs [79].

\section{Technology}

The application of REBA in manufacturing technology is defined by activities such as computer repair [77] or the manufacturing of electrical products [86]. In addition, it was combined with other methods such as OCRA to study the ergonomic assessment of electric motor assembly line operators [69]. Felekoglu and Tasan [70] have replaced traditional REBA assessment with Kinect sensors and electrogoniometers.

\section{Production Lines}

Many authors analysed production lines for automotive elements [84], plastics [83] or brick furnaces [81] using the REBA method. Conversely, Cornell University [72] developed a REBA-inspired musculoskeletal discomfort questionnaire, the AnyBody Modeling System (AMS) and electromyography measurements that identified the musculoskeletal disorders of employees on a harness assembly line.

At other times, the method was applied individually or in conjunction with other methods in packing factories dealing with varied orders [85], beverages [65] and even minerals [68], or in operations carried out by potters and sculptors [80] who suffer curvature in various parts of the body derived from forced postures.

In rubber production in Iran, Samanei et al. [82] combined the REBA and NMQ methods with a subsequent results analysis using SPSS software, concluding by identifying the need for immediate intervention in the lumbar region.

In sand-dredging operations in Udupi (India) [78], the REBA method, with a 12-point assessment, advised immediate intervention to reduce injuries, specifically in the lower back, as did the assessment by Hanson et al. [73] in manual collection operations. Furthermore, recent studies in the United Kingdom [74] gathered information on the effects of individual skills on job performance and safety in the workplace as well as human well-being, to design more inclusive work practices.

\subsubsection{Transportation and Storage}

Table 6 shows the four publications that have applied REBA individually or collectively in the study of forced postures related to transportation and storage.

Table 6. Transportation and storage.

\begin{tabular}{cccc}
\hline Reference & Country & Year & Objective \\
\hline$[87]$ & USA & 2012 & Ergonomic methods in the transport of people with reduced mobility. \\
{$[88]$} & India & 2016 & REBA and RULA in industrial vehicle operations. \\
{$[89]$} & China & 2019 & REBA and RULA on industrial vehicle drivers. \\
{$[90]$} & India & 2018 & REBA and NMQ in the railway sector. \\
\hline
\end{tabular}


There were two publications combining RULA and REBA. In the first, Balaji and Alphin [88] took photographs of operators who handled industrial excavators, observing that $46 \%$ of workers were exposed to high levels of danger; this resulted in the tasks being optimized and redesigned. In the second, Bora et al. [89] evaluated posture parameters in industrial vehicles using CATIA software.

Ahmed et al. [87], using a combination of ergonomic methods, assessed bus drivers who transported people with reduced mobility, looking at three different wheeled mobility devices: manual, scooter and electric. The results determined a high level of risk during the WTORS (Wheelchair Clamping and Occupant Restriction System) procedure. In the railway sector, several authors [90] combined REBA and NMQ in the ergonomic study of 51 railway workers, determining that the shoulder was the most affected body area followed by the neck.

\subsubsection{Water Supply; Sewerage, Waste Management and Remediation Activities}

Table 7 shows two studies related to waste management.

Table 7. Water supply; sewerage, waste management and remediation activities.

\begin{tabular}{cccl}
\hline Reference & Country & Year & \multicolumn{1}{c}{ Objective } \\
\hline$[91]$ & Turkey & 2015 & REBA and RULA in waste collection tasks. \\
RE2] & Poland & 2013 & $\begin{array}{l}\text { REA, Firstbeat and stadiometry in the ergonomic study of solid } \\
\text { waste collectors. }\end{array}$ \\
\hline
\end{tabular}

Cakit [91] combined the REBA and RULA methods in the study of waste collection movements, mainly in lifting and unloading tasks, considering it essential that these tasks be changed as soon as possible. Jozwiak et al. [92], used REBA, FirstBeat and stadiometry in the ergonomic study of urban solid waste collectors.

\subsubsection{Professional, Scientific and Technical Activities}

Table 8 shows publications that focus on different professional, scientific and technical activities.

Table 8. Professional, scientific and technical activities.

\begin{tabular}{llll}
\hline Reference & Country & Year & Objective \\
\hline$[93]$ & Italy & 2017 & Ergonomic methods used on sales assistants. \\
{$[94]$} & USA & 2015 & REBA used in the preparation of laboratory samples. \\
\hline
\end{tabular}

In professionals working with laboratory sample preparation [94], the REBA method assessed six subtasks for each of the six tasks analysed, concluding there was a medium-high risk level in at least one subtask for each task.

This method was also used, in combination with others, in sales assistants in Italy [93].

3.1.7. Activities of Households as Employers; Undifferentiated Goods—and Services—Producing Activities of Households for Own Use

There are three publications related to activities of households in which the REBA method has been applied: Lim et al. [95], Lofqvist et al. [96] and Rui et al. [97], corresponding to vacuum cleaning work, basic household chores and tasks associated with drying clothes, respectively (Table 9). 
Table 9. Activities of households as employers; undifferentiated goods—and services—producing activities of households for own use.

\begin{tabular}{|c|c|c|c|}
\hline Reference & Country & Year & Objective \\
\hline [95] & South Korea & 2012 & REBA in vacuum cleaning work. \\
\hline [96] & Sweden & 2015 & REBA in household chores \\
\hline [97] & Singapore & 2018 & $\begin{array}{l}\text { REBA used to quantify exposure to musculoskeletal } \\
\text { hazards associated with drying clothes }\end{array}$ \\
\hline
\end{tabular}

\subsubsection{Education}

In the field of education, only Hashim et al. [98] combined REBA and RULA to assess the different positions students take while they do their schoolwork, demonstrating that the majority need immediate intervention to prevent greater prejudicial effects (Table 10).

Table 10. Education.

\begin{tabular}{cccc}
\hline Reference & Country & Year & Objective \\
\hline$[98]$ & Malaysia & 2012 & RULA and REBA on students while performing their schoolwork. \\
\hline
\end{tabular}

\subsubsection{Construction}

Table 11 shows studies related to construction.

Table 11. Construction.

\begin{tabular}{|c|c|c|c|}
\hline Reference & Country & Year & Objective \\
\hline [99] & India & 2018 & Ergonomic methods in the construction sector. \\
\hline [100] & USA & 2011 & $\begin{array}{l}\text { Ergonomic methods on prefabricated-panel construction } \\
\text { workers. }\end{array}$ \\
\hline [101] & Canada & 2018 & $\begin{array}{l}3 \mathrm{D} \text { body modelling to reduce musculoskeletal disorders } \\
\text { in construction. }\end{array}$ \\
\hline [102] & China & 2019 & $\begin{array}{l}\text { Creation of an ergonomic assessment tool to apply the } \\
\text { REBA method in construction. }\end{array}$ \\
\hline
\end{tabular}

Several authors [102] created an ergonomic assessment tool using videos that allowed for postures to be assessed while working. Kim et al. [100], for their part, demonstrated how the manufacture of goods from prefabricated panels negatively influenced the spinal column of the workers.

In addition, other authors [101] made use of new 3D technologies to screen workers in different workplaces thus reducing the costs derived from MSDs and correcting bad habits. Conversely, in Western Bengal (India), Chatterjee and Sahu [99] combined different ergonomic assessment methods to demonstrate that a more conciliatory schedule and rest times, accompanied by technical modifications in the workplace and the use of redesigned equipment, reduced the risk of MSD.

\subsubsection{Other Activities}

Table 12 includes studies that could not be classified in any of the above areas. 
Table 12. Other activities.

\begin{tabular}{|c|c|c|c|}
\hline Reference & Country & Year & Objective \\
\hline [103] & USA & 2019 & NMQ and REBA in aircraft maintenance. \\
\hline [104] & Turkey & 2017 & OWAS and REBA in an electrical equipment factory \\
\hline [105] & Canada & 2012 & $\begin{array}{l}\text { Eight ergonomic assessment methods in various industrial } \\
\text { sectors. }\end{array}$ \\
\hline [106] & India & 2015 & $\begin{array}{l}\text { REBA applied to women who carry a load of bricks around } \\
\text { their necks. }\end{array}$ \\
\hline [107] & Spain & 2017 & $\begin{array}{l}\text { Error detection in the real-life practice of ergonomic } \\
\text { assessment methods. }\end{array}$ \\
\hline [108] & Canada & 2014 & $\begin{array}{l}\text { REBA in African women who endure head loads during } \\
\text { pregnancy. }\end{array}$ \\
\hline [109] & Brazil & 2016 & REBA in the collection of molluscs. \\
\hline [110] & Brazil & 2014 & Translation of the REBA method into Portuguese. \\
\hline [111] & India & 2015 & REBA in bike repair. \\
\hline [112] & India & 2010 & $\begin{array}{l}\text { Ergonomic assessment methods in three key Jaipur } \\
\text { business sectors. }\end{array}$ \\
\hline [113] & India & 2010 & REBA in Jaipur stone carving. \\
\hline [114] & South Korea & 2017 & $\begin{array}{l}\text { OWAS, RULA and REBA in the ergonomic assessment of } \\
\text { armament cleaning. }\end{array}$ \\
\hline [115] & Poland & 2014 & $\begin{array}{l}\text { Comparative analysis of musculoskeletal load assessment } \\
\text { methods }\end{array}$ \\
\hline [116] & USA & 2019 & Reliability assessment of the REBA method. \\
\hline [117] & Canada & 2013 & $\begin{array}{l}\text { RULA and REBA in the ergonomic assessment of casual } \\
\text { work. }\end{array}$ \\
\hline [118] & Iran & 2011 & REBA in an engine oil company. \\
\hline [119] & USA & 2010 & $\begin{array}{l}\text { REBA, RULA and NIOSH used on firefighters and medical } \\
\text { emergency technicians. }\end{array}$ \\
\hline [120] & USA & 2015 & REBA and RULA used on librarians. \\
\hline
\end{tabular}

The REBA method has been translated into other languages such as Portuguese [110]. Its reliability was also evaluated in 2019 by Schwartz et al. [116]. Moreover, it has been compared to other methods [115], raising the possibility of creating a comprehensive method for all work tasks and all body parts. Diego-Mas et al. [107] produced a study that detected the anomalies of different ergonomic assessment methods.

In Jaipur, India, two studies by Mukhopadhyay analysed the ergonomic assessment of operators in three artisanal sectors [112] as well as in stone carving [113]. Other authors assessed African women as they carried out two tasks related to loading bricks on their heads [106] and the load variance during pregnancy [108]. Bicycle repair [111] and marine mollusc collection [109] were also assessed using the REBA method.

Furthermore, the use of ergonomic assessment methods is common in areas such as aircraft maintenance [103], electrical equipment manufacture [104], armament cleaning tasks [114], engine oil companies [118], various industrial sectors [105] and even in multitasking jobs [117].

Yuan [120] assessed 39 employees from nine different library divisions on two occasions by combining the REBA and RULA methods. The workers' bad habits were improved once action guidelines were established.

Finally, REBA was also combined with other evaluation methods in the case of firefighters and medical emergency technicians [119].

\subsection{Analysis by Country}

The REBA method has been applied in 91 cases and in 24 different countries. The country where the highest number of studies has been carried out is India, with a total of 16; followed by the USA with 11; Iran and Turkey with eight; Canada and South Korea with seven; Brazil with five; Poland with four; Italy with three; Spain, Portugal, Malaysia, The United Kingdom, China, Sweden, and Israel 
with two, and Nigeria, Germany, Mexico, Croatia, Tunisia, Singapore, Cuba, and Venezuela with one publication each (Figure 2). One can observe that approximately $50 \%$ of the countries where REBA was used are in the process of developing.

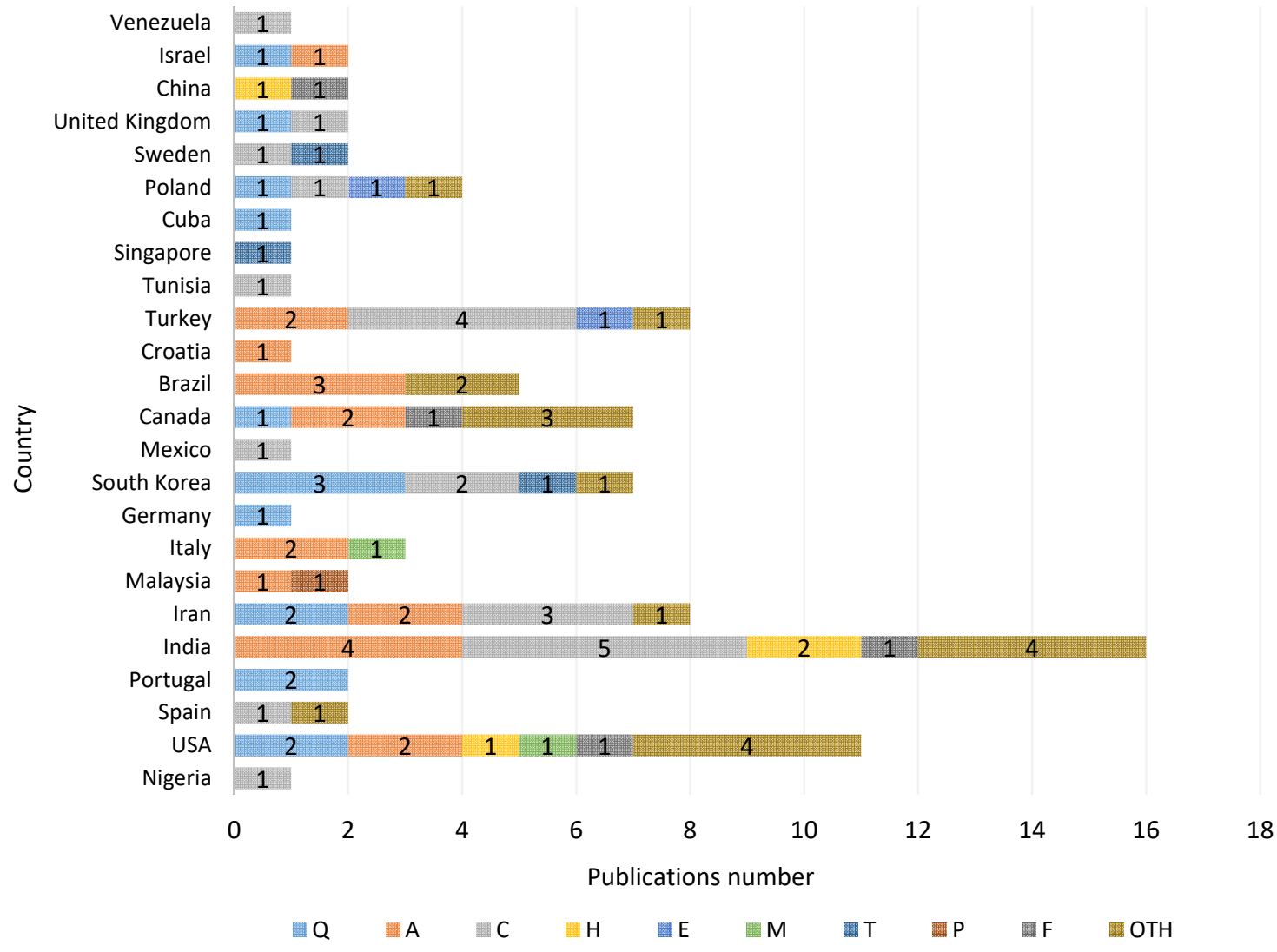

Figure 2. Publications by field and by country (see abbreviations Table 2).

In "manufacturing", five REBA applications in India and four in Turkey stand out. In turn, in "agriculture, forestry and fishing", four research studies in India and three in Brazil are highlighted. In "other activities", four studies in the USA and India and three in Canada stand out.

The USA is one of the countries with the highest number of contributions over diverse fields: human health and social work activities (2), agriculture, forestry and fishing (2), transportation and storage (1), professional, scientific and technical activities (1), construction (1) and others activities (4).

If you look at the United Kingdom, the country where the REBA method arose, there were only two studies in which the method was applied. This fact is countered by the much higher use of other methods, such as OWAS [13], in its country of origin [5]. Perhaps this is because the REBA method is more recent (the year 2000) than OWAS (1977).

\subsection{Analysis by Year}

The year with the highest number of publications was 2015, when there were fourteen in seven different areas, followed by 2017 and 2018 with twelve publications and 2016 and 2019 with ten (Figure 3). The years when there were the lowest number of research studies were 2007, 2008 and 2011 with two publications and 2006 with only one. On the other hand, over the years spanning the bibliographic review, there is no indication of any REBA method being applied in 2009 (Figure 3). 


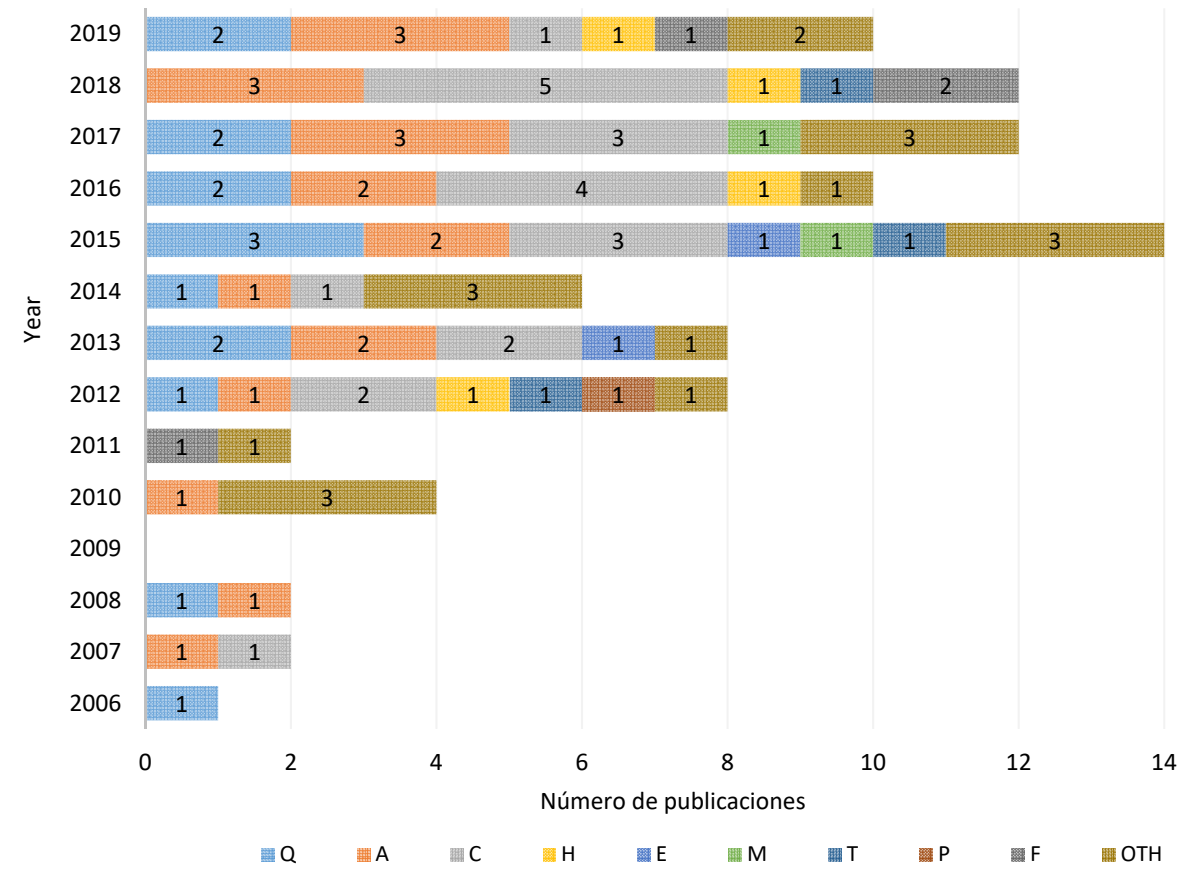

Figure 3. Publications by field and by year.

Thanks to society's awareness of the risks of MSD in the workplace, the publication of studies is growing exponentially over recent years, no doubt because of the developments in information and communication technologies, as mentioned before.

\subsection{Analysis by Journal}

The journals that most stand out are: "Work-A Journal of Prevention Assessment and Rehabilitation" with $18.68 \%$ of the publications and the "International Journal of Industrial Ergonomics" with 15.38\% (Table 13). "Applied Ergonomics", "Human Factors and Ergonomics in Manufacturing and Service Industries", "Journal of the Faculty of Engineering and Architecture of Gazi University" and the "International Journal of Occupational Safety and Ergonomics" are next with 3.30\% each (Table 13).

\subsection{Combination with Other Methods}

REBA is normally applied in conjunction with other assessment methods for musculoskeletal disorders. The REBA method [12] is mainly used to evaluate forced postures (Figure 1). However, it is sometimes combined with methods that study other risk factors. One of them, the RULA method, is also used to analyse repetitive movements (associated with REBA) [6]. Due to these considerations, some studies present a broader and more complete analysis [46,66].

In 47 of the studies reviewed, REBA is applied along with other methods [31,40,41,43,46,48,49,51-58, $63-69,71,75,76,79,80,82,83,87-93,98-100,103-105,112,114,117,119,120]$. These 47 results are included in the following categories: "human health and social work activities", "agriculture, forestry and fishing", "manufacturing", "transportation and storage", "water supply; sewerage, waste management and remediation activities", "professional, scientific and technical activities", "education", "construction" and "other activities". Of these, "agriculture, forestry and fishing" stands out with 13 studies, followed by "manufacturing" with 12 . Thanks to the combined use of the methods, the upper limbs, trunk, neck and lower extremities can be evaluated with greater precision [12]. 
Table 13. Number of publications per scientific journal, knowledge categories (Web of Science), impact factor, rank and quartile (2018).

\begin{tabular}{|c|c|c|c|c|c|}
\hline Journal & $\mathbf{P}^{*}$ & Impact Factor & Categories & Rank & Quartile \\
\hline $\begin{array}{l}\text { Work-A Journal of Prevention Assessment and Rehabilitation } \\
\text { Health Promotion Perspectives }\end{array}$ & 17 & 1.009 . & Public, environmental and occupational health-SSCI & $138 / 164$ & Q4 \\
\hline International Journal of Industrial Ergonomics & 14 & No intpact iactur. & $\begin{array}{l}\text { Ergonomics-SSCI } \\
\text { Engineering, industrial-SCIE }\end{array}$ & $\begin{array}{l}7 / 16 \\
28 / 46\end{array}$ & $\begin{array}{l}\mathrm{Q} 2 \\
\mathrm{Q} 3\end{array}$ \\
\hline International Journal of Injury Control and Safety Promotion & 1 & 0.87 & Public, environmental and occupational health-SSCI & $146 / 164$ & Q4 \\
\hline Safety Science & 1 & 3.619 & Engineering, industrial-SCIE & $10 / 46$ & Q1 \\
\hline Journal of Clinical and Analytical Medicine & 1 & No impact factor. & Operations research and management science-SCIE & $16 / 84$ & $\mathrm{Q} 1$ \\
\hline $\begin{array}{l}\text { Human Factors and Ergonomics in Manufacturing and Service } \\
\text { Industries }\end{array}$ & 3 & 1.000 & $\begin{array}{l}\text { Ergonomics-SSCI } \\
\text { Engineering, manufacturing-SCIE }\end{array}$ & $\begin{array}{l}13 / 16 \\
45 / 49\end{array}$ & $\begin{array}{l}\text { Q4 } \\
\text { Q4 }\end{array}$ \\
\hline $\begin{array}{l}\text { Global Nest Journal } \\
\text { International Journal on Working Conditions }\end{array}$ & $\begin{array}{l}1 \\
2\end{array}$ & $\begin{array}{l}0.869 \\
\text { No impact factor. }\end{array}$ & Environmental sciences-SCIE & 232/251 & $\mathrm{Q} 4$ \\
\hline $\begin{array}{l}\text { Journal of the Faculty of Engineering and Architecture of Gazi } \\
\text { University }\end{array}$ & 3 & 0.652 & Engineering, multidisciplinary_SCIE & $76 / 88$ & Q4 \\
\hline Journal of Back and Musculoskeletal Rehabilitation & 1 & 0.814 & $\begin{array}{l}\text { Orthopedics-SCIE } \\
\text { Rehabilitation-SCIE }\end{array}$ & $\begin{array}{l}65 / 76 \\
60 / 65 \\
112 / 251\end{array}$ & $\begin{array}{l}\text { Q4 } \\
\text { Q4 }\end{array}$ \\
\hline International Journal of Environmental Research and Public Health & 1 & 2.468 & $\begin{array}{l}\text { Environmental Sciences-SCIE } \\
\text { Public, environmental and occupational health-SSCI } \\
\text { Public, environmental and occupational health-SCIE }\end{array}$ & $\begin{array}{l}11 / 201 \\
38 / 164 \\
67 / 186\end{array}$ & Q1 \\
\hline Environmental Health and Preventive Medicine & 1 & 1.568 & $\begin{array}{l}\text { Public, environmental and occupational health-SSCI } \\
\text { Public, environmental and occupational health-SCIE }\end{array}$ & $\begin{array}{l}88 / 164 \\
120 / 186\end{array}$ & $\begin{array}{l}2 \\
\mathrm{Q} 3 \\
\mathrm{Q} 3\end{array}$ \\
\hline Asia-Pacific Journal of Public Health & 1 & 1.743 & $\begin{array}{l}\text { Public, environmental and occupational health-SSCI } \\
\text { Public, environmental and occupational health-SCIE }\end{array}$ & $\begin{array}{l}73 / 164 \\
108 / 186\end{array}$ & $\mathrm{Q} 2$ \\
\hline International Journal of Occupational Safety and Ergonomics & 3 & 1.377 & $\begin{array}{l}\text { Ergonomics-SSCI } \\
\text { Public, environmental and occupational health-SSCI }\end{array}$ & $\begin{array}{l}9 / 16 \\
110 / 164\end{array}$ & $\begin{array}{ll}2 \\
\mathrm{Q} 3 \\
\mathrm{Q} 3\end{array}$ \\
\hline Journal of Occupational Health & 1 & 1.8 & Public, environmental and occupational health-SCIE & $105 / 186$ & $\mathrm{Q} 3$ \\
\hline Cahiers Agricultures & 1 & 0.78 & $\begin{array}{l}\text { Agriculture, multidisciplinary-SCIE } \\
\text { Agronomy-SCIE }\end{array}$ & $\begin{array}{l}38 / 57 \\
63 / 89\end{array}$ & $\begin{array}{l}\mathrm{Q} 3 \\
\mathrm{Q} 3\end{array}$ \\
\hline Iranian Journal of Public Health & 1 & 1.225 & $\begin{array}{l}\text { Public, environmental and occupational health-SSCI } \\
\text { Public, environmental and occupational health-SCIE }\end{array}$ & $\begin{array}{l}122 / 164 \\
149 / 186\end{array}$ & $\begin{array}{l}-1 \\
\mathrm{Q} 3 \\
\mathrm{Q} 4\end{array}$ \\
\hline Journal of Health and Safety at Work & 1 & No impact factor. & & & \\
\hline & & & $\begin{array}{l}\text { Behavioral sciences-SCIE } \\
\text { Enoineering industrial-SCIE }\end{array}$ & $\begin{array}{l}20 / 53 \\
18 / 46\end{array}$ & $\begin{array}{l}\mathrm{Q} 2 \\
\mathrm{O} 2\end{array}$ \\
\hline Human Factors & 1 & 2.649 & $\begin{array}{l}\text { Ergonomics-SSCI } \\
\text { Psychology_SCIE }\end{array}$ & $\begin{array}{l}2 / 16 \\
25 / 77 \\
24 / 8\end{array}$ & $\mathrm{Q} 1$ \\
\hline Dyna Colombia & 1 & No impact factor. & Psychology, applied-SSCI & $24 / 82$ & \\
\hline Anaesthesia & 1 & 5.879 & Anesthesiology_SCIE & $4 / 31$ & Q1 \\
\hline Aquacultural Engineering & 1 & 2.143 & $\begin{array}{l}\text { Agricultural, engineering-SCIE } \\
\text { Fisheries-SCIE }\end{array}$ & $\begin{array}{l}5 / 13 \\
17 / 52\end{array}$ & $\mathrm{Q}^{2}$ \\
\hline Journal of Minimally Invasive Gynecology & 1 & 2.547 & Obstetrics and Gynecology- SCIE & $25 / 83$ & $\mathrm{Q} 2$ \\
\hline International Journal of Clothing Science and Technology & 1 & 0.752 & $\begin{array}{l}\text { Materials science, textiles-SCIE } \\
\text { Ergonomics-SSCI }\end{array}$ & $\begin{array}{l}12 / 24 \\
3 / 16\end{array}$ & $\mathrm{Q} 2$ \\
\hline Applied Ergonomics & 3 & 2.610 & Psychology, applied-SSCI & $25 / 82$ & \\
\hline
\end{tabular}


Table 13. Cont.

\begin{tabular}{|c|c|c|c|c|c|}
\hline Journal & $P^{*}$ & Impact Factor & Categories & Rank & Quartile \\
\hline & & & Engineering, industrial—SCIE & $20 / 46$ & \\
\hline Medycyna Pracy & 1 & 0.778 & Public, environmental and occupational health—SCIE & $171 / 186$ & Q4 \\
\hline International Journal of Occupational and Environmental Health & 2 & 0.973 & Public, environmental and occupational health—SSCI & $141 / 164$ & Q4 \\
\hline \multirow{3}{*}{ International Journal of Dental Hygiene } & & $0.9 / 3$ & Public, environmental and occupational health—SCIE & $165 / 186$ & Q4 \\
\hline & 1 & 1.233 & Dentistry, oral surgery and medicine-SCIE & $68 / 91$ & Q3 \\
\hline & & & Engineering, industrial—SCIE & $21 / 46$ & Q2 \\
\hline \multirow{3}{*}{ Ergonomics } & & & Ergonomics-SSCI & $5 / 16$ & Q2 \\
\hline & 1 & 2.181 & Psychology—SCIE & $38 / 77$ & $\mathrm{Q} 2$ \\
\hline & & & Psychology, applied-SSCI & $35 / 82$ & $\mathrm{Q} 2$ \\
\hline Journal of Physical Therapy Science & 2 & 0.392 & Rehabilitation-SCIE & $61 / 64$ & $\mathrm{Q} 4$ \\
\hline Brazilian Journal of Physical Therapy & 1 & 1.879 & Orthopedics-SCIE & $38 / 76$ & Q2 \\
\hline Seefor-South-East European Forestry & 1 & No impact factor. & Rehabilitation-SCIE & $27 / 65$ & Q2 \\
\hline \multirow{3}{*}{ Journal of Construction Engineering and Management } & & 2.734 & Construction and Building Technology_SCIE & $15 / 63$ & Q1 \\
\hline & 2 & & Engineering, civil-SCIE & $32 / 132$ & $\mathrm{Q} 1$ \\
\hline & & & Engineering, industrial -SCIE & $17 / 46$ & $\mathrm{Q} 2$ \\
\hline International Journal of Precision Engineering and Manufacturing & 1 & 1.779 & Engineering, manufacturing & $33 / 49$ & Q3 \\
\hline & & & Engineering, mechanical-SCIE & $64 / 129$ & Q2 \\
\hline $\begin{array}{l}\text { Journal of Clinical and Diagnositic Research } \\
\text { Journal of Chemical Health and Safety }\end{array}$ & 1 & No impact factor. & & & \\
\hline Design Journal & 1 & No impact factor. & & & \\
\hline Indian Journal of Occupational and Environmental Medicine & 1 & No impact factor. & & & \\
\hline & 1 & 2983 & Agricultural engineering -SCIE & $4 / 13$ & Q2 \\
\hline Biosystems Engineering & & & Agriculture, multidisciplinary -SCIE & $7 / 57$ & $\mathrm{Q} 1$ \\
\hline International Journal of Workplace Health Management & 1 & No impact factor. & & & \\
\hline Revista Arvore & 1 & 0.367 & Forestry-SCIE & $64 / 67$ & Q4 \\
\hline $\begin{array}{l}\text { Progress in Community Health Partnerships-Research Education } \\
\text { and Action }\end{array}$ & 1 & 0.64 & Public, environmental and occupational health—SSCI & $153 / 164$ & Q4 \\
\hline International Journal of Occupational and Environmental Medicine & 1 & No impact factor. & & & \\
\hline Fresenius Environmental Bulletin & 1 & 0.691 & Environmental Sciences_SCIE & $240 / 251$ & $\mathrm{Q} 4$ \\
\hline Laryngoscope & 1 & 2.343 & Medicine, research and experimental- SCIE & $78 / 136$ & Q3 \\
\hline Logforum & 1 & No impact factor. & Otorhinolaryngology—SCIE & $12 / 42$ & Q2 \\
\hline Journal of Agricultural Engineering & 1 & No impact factor. & & & \\
\hline Health Scope & 1 & No impact factor. & & & \\
\hline Journal of Research in Health Sciences & 1 & No impact factor. & & & \\
\hline
\end{tabular}




\section{Conclusions}

The REBA method is mainly used for the analysis of forced postures. It is not useful for the evaluation of repetitive movements.

Although this method was initially intended to be applied to the analysis of forced postures in personnel related to the human health and social work activities field, as well as various activities in the service sector, it can be applied to any sector or labour activity. In fact, it is observed that the application number is greater in other knowledge categories than in the original field.

In this literature review, the REBA method was mainly applied to three areas: "manufacturing", "agriculture, forestry and fishing" and "other activities".

It is often widely used in combination with other methods and has was greatly by the digitization of scientific content over the last decade.

In addition, unlike other methods which that are combined with REBA, this one focuses on the upper limbs (arm, forearm and wrist), lower extremities, trunk and neck.

In the Americas, its application is highly diversified over the different fields of knowledge. Conversely, in Asia, it is applied more specifically in two sectors: "manufacturing" and "agriculture, forestry and fishing".

In countries immersed in the development process, it is not easily used since they do not have enough technology or information on the method. However, the fact that approximately $50 \%$ of the studies were carried out in developing countries may be an indicator of sustainable processes starting in companies there.

The journals that have published the most studies on applying the REBA method are "Work-A Journal of Prevention Assessment and Rehabilitation" and the "International Journal of Industrial Ergonomics".

Author Contributions: Conceptualization, M.H.-G., M.G.-G., M.D.-P., and Á.-J.C.-F.; methodology, M.H.-G., M.G.-G., M.D.-P., and Á.-J.C.-F.; software, M.H.-G., M.G.-G., M.D.-P., and Á.-J.C.-F.; validation, M.H.-G., M.G.-G., M.D.-P., and Á.-J.C.-F.; formal analysis, M.H.-G., M.G.-G., M.D.-P., and Á.-J.C.-F.; research, M.H.-G., M.G.-G., M.D.-P., and Á.-J.C.-F.; resources, M.H.-G., M.G.-G., M.D.-P., and Á.-J.C.-F.; data curation, M.H.-G., M.G.-G., M.D.-P., and Á.-J.C.-F.; writing-original draft preparation, M.H.-G., M.G.-G., M.D.-P., and Á.-J.C.-F.; writing-review and editing, M.H.-G., M.G.-G., M.D.-P., and Á.-J.C.-F.; visualization, M.H.-G., M.G.-G., M.D.-P., and Á.-J.C.-F.; M.H.-G., M.G.-G., M.D.-P., and Á.-J.C.-F.; project administration, M.H.-G., M.G.-G., M.D.-P., and Á.-J.C.-F. All authors have read and agreed to the published version of the manuscript.

Funding: This research received no external funding.

Acknowledgments: Laboratory-Observatory Andalusian Working Conditions in the Agricultural Sector (LASA; C.G. 401487) and the Research Own Plan of the University of Almería.

Conflicts of Interest: The authors declare no conflicts of interest.

\section{References}

1. International Ergonomics Association (IEA). What Is Ergonomics? Available online: https://iea.cc/what-isergonomics/ (accessed on 3 April 2020).

2. World Health Organization (WHO). Musculoskeletal Conditions. Available online: https://www.who.int/ news-room/fact-sheets/detail/musculoskeletal-conditions (accessed on 3 April 2020).

3. NIOSH. Technical Reports. Division of Biomedical, and Behavioral Science. In Work Practices Guide for Manual Lifting; US Dept. of Health and Human Services, Public Health Service, Centers for Disease Control, National Institute for Occupational Safety and Health, Division of Biomedical and Behavioral Science: Cincinnati, OH, USA, 1981; pp. 1-198.

4. Asensio-Cuesta, S.; Bastante-Ceca, M.; Diego-Más, J. Evaluación Ergonómica de Puestos de Trabajo; Paraninfo: Madrid, Spain, 2012.

5. Gómez-Galán, M.; Pérez-Alonso, J.; Callejon-Ferre, A.J.; López-Martínez, J. Musculoskeletal disorders: OWAS review. Ind. Health 2017, 55. [CrossRef] [PubMed] 
6. McAtamney, L.; Corlett, E.N. RULA: A survey method for the investigation of work-related upper limb disorders. Appl. Ergon. 1993, 24, 91-99. [CrossRef]

7. Moore, J.S.; Garg, A. The Strain Index: A proposed method to analyze jobs for risk of distal upper extremity disorders. Am. Ind. Hyg. Assoc. J. 1995, 56, 443-458. [CrossRef] [PubMed]

8. James, C.P.A.; Harburn, K.L.; Kramer, J.F. Cumulative trauma disorders in the upper extremities: Reliability of the postural and repetitive risk-factors index. Arch. Phys. Med. Rehabil. 1997, 78, 860-866. [CrossRef]

9. García, C.; Chirivela, C.; Page del Pozo, A.; Moraga, R.; Jorquera, J. Método Ergo IBV. Evaluación de Riesgos Laborales Asociados a la Carga Física; Instituto de Biomecánica de Valencia (IBV): Valencia, Spain, 1997.

10. Colombini, D. An observational method for classifying exposure to repetitive movements of the upper limbs. Ergonomics 1998, 41, 1261-1289. [CrossRef]

11. Kemmlert, K. A method assigned for the identification of ergonomic hazards-PLIBEL. Appl. Ergon. 1995, 26, 199-211. [CrossRef]

12. Hignett, S.; Mcatamney, L. Rapid entire body assessment (REBA). Appl. Ergon. 2000, 31, 201-205. [CrossRef]

13. Karhu, O.; Kansi, P.; Kuorinka, I. Correcting working postures in industry: A practical method for analysis. Appl. Ergon. 1977, 8, 199-201. [CrossRef]

14. Corlett, E.; Madeley, S.; Manenica, I. Posture targetting: A technique for recording working postures. Ergonomics 1979, 22, 357-366. [CrossRef]

15. Kilbom, A.; Persson, J.; Jonsson, B. Risk factors for workrelated disorders of the neck and shoulder-With special emphasis on working postures and movements. In The Ergonomics of Working Postures; Corlett, E.N., Wilson, J., Manenica, I., Eds.; Taylor and Francis: London, UK, 1986; pp. 44-53.

16. Buchholz, B.; Paquet, V.; Punnett, L.; Lee, D.; Moir, S. PATH: A work sampling-based approach to ergonomic job analysis for construction and other non-repetitive work. Appl. Ergon. 1996, 27, 177-187. [CrossRef]

17. NIOSH (National Institute for Occupational Safety and Health). Work Practices Guide for Manual Lifting; NIOSH Technical Report; NIOSH: Cincinnaty, OH, USA, 1981; pp. 81-122.

18. Instituto Nacional de Seguridad e Higiene en el Trabajo (INSHT). Guía Técnica para la Evaluación y Prevención de los Riesgos Relativos a la Manipulación Manual de Cargas; Guías Técnicas; INSHT: Madrid, Spain, 1998. Available online: https:/www.insst.es/documents/94886/509319/GuiatecnicaMMC.pdf/27a8b126-a827-4eddaa4c-7c0ca0a86cda (accessed on 1 November 2019).

19. Snook, S.H.; Ciriello, V.M. The design of manual handling tasks: Revised tables of maximum acceptable weights and forces. Ergonomics 1991, 34, 1197-1213. [CrossRef] [PubMed]

20. Jürgens, W.W.; Mohr, D.; Pangert, R.; Pernack, E.; Schultz, K.; Steinberg, U. Handlungsanleitung zur Beurteilung der Arbeitsbedingungen beim Heben und Tragen von Lasten; LASI Veröffentlichung: Saarbrücken, Germany, 2001; pp. 1-37.

21. Monnington, S.; Quarrie, C.; Pinder, A.; Morris, L. Development of manual handling assessment charts (MAC) for health and safety inspectors. In Contemporary Ergonomics; CRC Press: London, UK, 2003; pp. 3-8.

22. Liberty-Mutual. Manual Materials Handling Tables. 2011. Available online: http://libertymmhtables. libertymutual.com/CM_LMTablesWeb/pdf/LibertyMutualTables.pdf (accessed on 2 November 2019).

23. von Macard, T.; Rosenhahn, B.; Black, M.J.; Pons-Moll, G. Spare inertial poser: Automatic 3D human pose estimation from sparse IMUs. Comput. Graph. Forum 2017, 36, 349-360. [CrossRef]

24. ViveLab Ergo. Ergonomic Verification in 3D Virtual Space. Available online: https://www.vivelab.cloud/ (accessed on 3 April 2020).

25. INSST. NTP 601: Evaluación de las Condiciones de Trabajo: Carga Postural. Método REBA; Instituto de Seguridad e Higiene del Trabajo: Madrid, Spain, 2001.

26. Takala, E.P.; Pehkonen, I.; Forsman, M.; Hansson, G.A.; Mthiassen, S.E.; Neumann, W.P.; Sjogaard, G.; Veiersted, K.B.; Westgaard, R.H.; Winkel, J. Systematic evaluation of observational methods assessing biomechanical exposures at work. Scand. J. Work Environ. Health 2010, 36, 3-24. [CrossRef] [PubMed]

27. Eurostat. NACE Rev. 2. Structure and Explanatory Notes. Available online: https: //ec.europa.eu/eurostat/documents/1965800/1978839/NACE_rev2_explanatory_notes_EN.pdf/b09f2cb45dac-4118-9164-bcc39b791ef5 (accessed on 18 March 2020).

28. Addinsoft. XLSTAT2019, Analyse de Données et Statistique Avec MS Excel; Addinsoft: Paris, France, 2019; Available online: https://www.xlstat.com/es/empresa (accessed on 24 November 2019).

29. Aguillo, I. Tecnologías, investigación y futuro de la profesión. Prof. Inf. 2012, 21, 5-8. [CrossRef] 
30. Abdollahzade, F.; Mohammadi, F.; Dianat, I.; Asghari, E.; Asghari-Jafarabadi, M.; Sokhanvar, Z. Working posture and its predictors in hospital operating room nurses. Health Promot. Perspect. 2016, 6, 17-22. [CrossRef]

31. Bartnicka, J. Knowledge-based ergonomic assessment of working conditions in surgical ward-A case study. Saf. Sci. 2015, 71, 178-188. [CrossRef]

32. Carneiro, P.; Martins, J.; Torres, M. Musculoskeletal disorder risk assessment in home care nurses. Work J. Prev. Assess. Rehabil. 2015, 51, 657-665. [CrossRef]

33. Grundgeiger, T.; Roewer, N.; Grundgeiger, J.; Hurtienne, J.; Happel, O. Body posture during simulated tracheal intubation: GlideScope (R) videolaryngoscopy vs. Macintosh direct laryngoscopy for novices and experts. Anaesthesia 2015, 70, 1375-1381. [CrossRef]

34. Hignett, S.; Gyi, D.; Calkins, L.; Jones, L.; Moss, E. Human Factors Evaluation of Surgeons' Working Positions for Gynecologic Minimal Access Surgery. J. Minim. Invasive Gynecol. 2017, 24, 1178-1184. [CrossRef]

35. Janowitz, I.L.; Gillen, M.; Ryan, G.; Rempel, D.; Trupin, L.; Swig, L.; Mullen, K.; Rugulies, R.; Blanc, P.D. Measuring the physical demands of work in hospital settings: Design and implementation of an ergonomics assessment. Appl. Ergon. 2006, 37, 641-658. [CrossRef]

36. Kim, J.; Park, B.Y.; Mun, S.J.; Shim, J.; Choi, E.S.; Noh, H. Differences in plantar pressure by REBA scores in dental hygienists. Int. J. Dent. Hyg. 2019, 17, 177-182. [CrossRef] [PubMed]

37. Kim, T.; Roh, H. Analysis of risk factors for work-related musculoskeletal disorders in radiological technologists. J. Phys. Ther. Sci. 2014, 26, 1423-1428. [CrossRef] [PubMed]

38. Noh, H.; Roh, H. Approach of industrial physical therapy to assessment of the musculoskeletal system and ergonomic risk factors of the dental hygienist. J. Phys. Ther. Sci 2013, 25, 821-826. [CrossRef]

39. Pascual, S.A.; Naqvi, S. An investigation of ergonomics analysis tools used in industry in the identification of work-related musculoskeletal disorders. Int. J. Occup. Saf. Ergon. 2008, 14, 237-245. [CrossRef] [PubMed]

40. Rafeemanesh, E.; Jafari, Z.; Kashani, F.O.; Rahimpour, F. A study on job postures and musculoskeletal illnesses in dentists. Int. J. Occup. Med. Environ. Health 2013, 26, 615-620. [CrossRef] [PubMed]

41. Ratzon, N.Z.; Bar-Niv, N.A.; Froom, P. The effect of a structured personalized ergonomic intervention program for hospital nurses with reported musculoskeletal pain: An assigned randomized control trial. Work J. Prev. Assess. Rehabil. 2016, 54, 367-377. [CrossRef]

42. Torres, M.; Carneiro, P.; Arezes, P. WMSDs in nurses that provide care in surgical internment context. Int. J. Work. Cond. 2017, 14, 33-49.

43. Torres, Y.; Vina, S. Evaluation and redesign of manual material handling in a vaccine production centre's warehouse. Work J. Prev. Assess. Rehabil. 2012, 41, 2487-2491. [CrossRef]

44. Vaisbuch, Y.; Aaron, K.A.; Moore, J.M.; Vaughan, J.; Ma, Y.F.; Gupta, R.; Jackler, R.K. Ergonomic hazards in otolaryngology. Laryngoscope 2019, 129, 370-376. [CrossRef]

45. Camargo, V.M.; Hembecker, P.K.; Lima, I.A.X.; Moro, A.R.P.; Gontijo, L.A. Ergonomic assessment in a producer of ornamental plants in Brazil. Int. J. Work. Cond. 2015, 10, 138-151.

46. Cremasco, M.M.; Giustetto, A.; Caffaro, F.; Colantoni, A.; Cavallo, E.; Grigolato, S. Risk assessment for musculoskeletal disorders in forestry: A comparison between RULA and REBA in the manual feeding of a wood-chipper. Int. J. Environ. Res. Public Health 2019, 16, 793. [CrossRef] [PubMed]

47. Das, B.; Gangopadhyay, S. Prevalence of musculoskeletal disorders and physiological stress among adult, male potato cultivators of West Bengal, India. Asia-Pac. J. Public Health 2015, 27, 1669-1682. [CrossRef] [PubMed]

48. Das, B.; Ghosh, T.; Gangopadhyay, S. Assessment of ergonomic and occupational health-related problems among female prawn seed collectors of Sunderbans, West Bengal, India. Int. J. Occup. Saf. Ergon. 2012, 18, 531-540. [CrossRef] [PubMed]

49. Das, B.; Ghosh, T.; Gangopadhyay, S. Child work in agriculture in West Bengal, India: Assessment of musculoskeletal disorders and occupational health problems. J. Occup. Health 2013, 55, 244-258. [CrossRef] [PubMed]

50. De Oliveira, C.C.; Xavier, A.A.D.; Ulbricht, L.; Moro, A.R.P.; Belinelli, M.M. Health in the rural environment: A postural evaluation of milking workers in Brazil. Cah. Agric. 2018, 27. [CrossRef]

51. Deros, B.M.; Ali, M.H.; Mohamad, D.; Daruis, D.D.I. Ergonomic risk assessment on oil palm industry workers. Iran. J. Public Health 2016, 45, 44-51. 
52. Enez, K.; Nalbantoglu, S.S. Comparison of ergonomic risk assessment outputs from OWAS and REBA in forestry timber harvesting. Int. J. Ind. Ergon. 2019, 70, 51-57. [CrossRef]

53. Houshyar, E.; Kim, I.J. Understanding musculoskeletal disorders among Iranian apple harvesting laborers: Ergonomic and stop watch time studies. Int. J. Ind. Ergon. 2018, 67, 32-40. [CrossRef]

54. Jones, T.; Kumar, S. Comparison of ergonomic risk assessments in a repetitive high-risk sawmill occupation: Saw-filer. Int. J. Ind. Ergon. 2007, 37, 744-753. [CrossRef]

55. Jones, T.; Kumar, S. Comparison of ergonomic risk assessment output in a repetitive sawmill occupation: Trim-saw operator. Work J. Prev. Assess. Rehabil. 2008, 31, 367-376.

56. Jones, T.; Kumar, S. Comparison of ergonomic risk assessment output in four sawmill jobs. Int. J. Occup. Saf. Ergon. 2010, 16, 105-111. [CrossRef] [PubMed]

57. Landekic, M.; Katusa, S.; Mijoc, D.; Sporcic, M. Assessment and comparison of machine operators' working posture in forest thinning. Seefor-South-East Eur. For. 2019, 10, 29-37. [CrossRef]

58. Pal, A.; Dhara, P.C. Work related musculoskeletal disorders and postural stress of the women cultivators engaged in uprooting job of rice cultivation. Indian J. Occup. Environ. Med. 2018, 22, 163-169. [CrossRef] [PubMed]

59. Riemer, R.; Bechar, A. Investigation of productivity enhancement and biomechanical risks in greenhouse crops. Biosyst. Eng. 2016, 147, 39-50. [CrossRef]

60. Schettino, S.; Campos, J.C.C.; Minette, L.J.; de Souza, A.P. Work precariousness: Ergonomic risks to operators of machines adapted for forest harvesting. Revista Arvore 2017, 41. [CrossRef]

61. Silver, K.; Hoffman, K.; Loury, S.; Fethke, N.B.; Liebman, A.; Manz, N.; Manock, S.; Andino, A.; Bradfield, M.; Morrissette, D.; et al. Campus-community partnership for farmworkers' health: Interventions for tomato workers in Tennessee. Prog. Community Health Partnersh. Res. Educ. Act. 2014, 8, 501-510. [CrossRef]

62. Taghavi, S.M.; Mokarami, H.; Ahmadi, O.; Stallones, L.; Abbaspour, A.; Marioryad, H. Risk factors for developing work-related musculoskeletal disorders during dairy farming. Int. J. Occup. Environ. Med. 2017, 8, 39-45. [CrossRef]

63. Unver-Okan, S.; Acar, H.H.; Kaya, A. Determination of work postures with different ergonomic risk assessment methods in forest nurseries. Fresenius Environ. Bull. 2017, 26, 7362-7371.

64. Gallo, R.; Mazzetto, F. Ergonomic analysis for the assessment of the risk of work-related musculoskeletal disorder in forestry operations. J. Agric. Eng. 2013, 44. [CrossRef]

65. Abaraogu, U.O.; Odebiyi, D.O.; Olawale, O.A. Association between postures and work-related musculoskeletal discomforts (WRMD) among beverage bottling workers. Work J. Prev. Assess. Rehabil. 2016, 54, 113-119. [CrossRef]

66. Boulila, A.; Ayadi, M.; Mrabet, K. Ergonomics study and analysis of workstations in Tunisian mechanical manufacturing. Hum. Factors Ergon. Manuf. Serv. Ind. 2018, 28, 166-185. [CrossRef]

67. Can, G.F.; Atalay, K.D.; Eraslan, E. Working posture analysis in fuzzy environment and ergonomic work station design recommendations. J. Fac. Eng. Gazi Univ. 2015, 30, 451-460.

68. Dehghani, F.; Zakerian, S.A.; Zare, A.; Omidi, F.; Moradpour, Z.; Eynipour, A.; Kakavandi, M.G. Ergonomic interventions for improving working postures associated with manual materials handling (case study: A mineral processing plant). J. Health Saf. Work 2016, 6, 85-94.

69. Escalona, L.Y.; Venot, R.S.; Escalona, E.; Yanes, L. The reality of the women who make our lives easier: Experience in a company that assemblies electric motors in Venezuela. Work J. Prev. Assess. Rehabil. 2012, 41, 1775-1777. [CrossRef]

70. Felekoglu, B.; Tasan, S.O. Ergonomic risk assessment for work-related musculoskeletal disorders: A systematic reactive/proactive integrated approach. J. Fac. Eng. Archit. Gazi Univ. 2017, 32, 777-793. [CrossRef]

71. Garcia-Garcia, M.; Sanchez-Lite, A.; Camacho, A.M.; Domingo, R. Analysis of postural assessment methods and virtual simulation tools into manufacturing engineering. Dyna-Colombia 2013, 80, 5-15.

72. Gonen, D.; Karaoglan, A.D.; Ocaktan, M.A.B.; Oral, A.; Aticti, H.; Kaya, B. A new risk assessment approach for the analysis of musculoskeletal disorders. J. Fac. Eng. Archit. Gazi Univ. 2018, 33, 423-438. [CrossRef]

73. Hanson, R.; Medbo, L.; Berlin, C.; Hansson, J. Manual picking from flat and tilted pallet containers. Int. J. Ind. Ergon. 2018, 64, 199-212. [CrossRef]

74. Hussain, A.; Case, K.; Marshall, R.; Summerskill, S. Using Ergonomic Risk Assessment Methods for Designing Inclusive Work Practices: A Case Study. Hum. Factors Ergon. Manuf. Serv. Ind. 2016, 26, 337-355. [CrossRef] 
75. Isler, M.; Kucuk, M.; Guner, M. Ergonomic assessment of working postures in clothing sector with scientific observation methods. Int. J. Cloth. Sci. Technol. 2018, 30, 757-771. [CrossRef]

76. Kee, D.; Karwowski, W. A comparison of three observational techniques for assessing postural loads in industry. Int. J. Occup. Saf. Ergon. 2007, 13, 3-14. [CrossRef] [PubMed]

77. Maldonado-Macias, A.; Realyvasquez, A.; Hernandez, J.L.; Garcia-Alcaraz, J. Ergonomic assessment for the task of repairing computers in a manufacturing company: A case study. Work J. Prev. Assess. Rehabil. 2015, 52, 393-405. [CrossRef] [PubMed]

78. Mohapatra, S.; Shaikh, A.; Nayak, P.; Navada, R. Hazards and health risks encountered by manual sand dredgers from Udupi, India: A cross-sectional study. J. Clin. Diagn. Res. 2017, 11, 11-17. [CrossRef] [PubMed]

79. Nagaraj, T.S.; Jeyapaul, R.; Mathiyazhagan, K. Evaluation of ergonomic working conditions among standing sewing machine operators in Sri Lanka. Int. J. Ind. Ergon. 2019, 70, 70-83. [CrossRef]

80. Sahu, S.; Moitra, S.; Maity, S.; Pandit, A.K.; Roy, B. A comparative ergonomics postural assessment of potters and sculptors in the unorganized sector in West Bengal, India. Int. J. Occup. Saf. Ergon. 2013, 19, 455-462. [CrossRef] [PubMed]

81. Sain, M.K.; Meena, M.L. Exploring the musculoskeletal problems and associated risk-factors among brick kiln workers. Int. J. Workplace Health Manag. 2018, 11, 395-410. [CrossRef]

82. Samaei, S.E.; Tirgar, A.; Khanjani, N.; Mostafaee, M.; Hosseinabadi, M.B. Effect of personal risk factors on the prevalence rate of musculoskeletal disorders among workers of an Iranian rubber factory. Work J. Prev. Assess. Rehabil. 2017, 57, 547-553. [CrossRef]

83. Sanjog, J.; Patel, T.; Chowdhury, A.; Karmakar, S. Musculoskeletal ailments in Indian injection-molded plastic furniture manufacturing shop-floor: Mediating role of work shift duration. Int. J. Ind. Ergon. 2015, 48, 89-98. [CrossRef]

84. Yoon, S.Y.; Ko, J.; Jung, M.C. A model for developing job rotation schedules that eliminate sequential high workloads and minimize between-worker variability in cumulative daily workloads: Application to automotive assembly lines. Appl. Ergon. 2016, 55, 8-15. [CrossRef]

85. Lasota, A.M. A REBA-based analysis of packers workload: A case study. LogForum 2014, 10, 87-95.

86. Moussavi-Najarkola, S.; Mirzaei, R. Assessment of musculoskeletal loads of electric factory workers by rapid entire body assessment. Health Scope 2012, 1, 71-79. [CrossRef]

87. Ahmed, M.; Campbell-Kyureghyan, N.; Frost, K.; Bertocci, G. Ergonomic evaluation of a wheelchair transportation securement system. Work J. Prev. Assess. Rehabil. 2012, 41, 4924-4930. [CrossRef] [PubMed]

88. Balaji, K.K.; Alphin, M.S. Computer-aided human factors analysis of the industrial vehicle driver cabin to improve occupational health. Int. J. Inj. Control Saf. Promot. 2016, 23, 240-248. [CrossRef] [PubMed]

89. Bora, S.; Bhalerao, Y.; Goyal, A.; Chakrabarti, D.; Chen, D.Z.; Bao, N.S.; Niu, X.; Garg, A. Computation of safety design indexes of industry vehicle operators based on the reach angle, the distance from elbow to ground and the popliteal height. Int. J. Ind. Ergon. 2019, 71, 155-164. [CrossRef]

90. Khan, M.R.; Singh, N.K. Prevalence of musculoskeletal disorders among Indian railway sahayaks. Int. J. Occup. Environ. Health 2018, 24, 27-37. [CrossRef]

91. Cakit, E. Assessment of the physical demands of waste collection tasks. Glob. Nest J. 2015, 17, $426-438$.

92. Jozwiak, Z.W.; Bortkiewicz, A.; Makowiec-Dabrowska, T.; Kapitaniak, B. Assessment of musculoskeletal load in refuse collectors. Med. Pracy 2013, 64, 507-519.

93. Capodaglio, E.M. Occupational risk and prolonged standing work in apparel sales assistants. Int. J. Ind. Ergon. 2017, 60, 53-59. [CrossRef]

94. Mork, M.A.; Choi, S.D. An ergonomic assessment of sample preparation job tasks in a chemical laboratory. J. Chem. Health Saf. 2015, 22, 23-32. [CrossRef]

95. Lim, D.; Cho, Y.K.; Choi, H.H.; Hwang, S.J.; Han, P.; Woo, D.G.; Hwang, G.; Kim, Y.H.; Chu, J.; Shin, J.; et al. Evaluation of loads imposed on muscles and joints by repeated vacuum cleaning works for estimation of a potentiality of musculo-skeletal disorder occurrence. Int. J. Precis. Eng. Manuf. 2012, 13, 429-438. [CrossRef]

96. Lofqvist, L.; Osvalder, A.L.; Bligard, L.O.; Pinzke, S. An analytical ergonomic risk evaluation of body postures during daily cleaning tasks in horse stables. Work J. Prev. Assess. Rehabil. 2015, 51, 667-682. [CrossRef] [PubMed] 
97. Rui, L.H.; Cheung, T.W.C.; Yang, Z.X.; Pratt, A.L. A pilot study: Exploring the musculoskeletal risk exposure associated with drying laundry using the public housing pipe-socket system amongst women in Singapore. Work J. Prev. Assess. Rehabil. 2018, 61, 449-461. [CrossRef] [PubMed]

98. Hashim, A.M.; Dawal, S.Z.M.; Yusoff, N. Ergonomic evaluation of postural stress in school workshop. Work J. Prev. Assess. Rehabil. 2012, 41, 827-831. [CrossRef] [PubMed]

99. Chatterjee, A.; Sahu, S. A physiological exploration on operational stance and occupational musculoskeletal problem manifestations amongst construction labourers of West Bengal, India. J. Back Musculoskelet. Rehabil. 2018, 31, 775-783. [CrossRef]

100. Kim, S.; Nussbaum, M.A.; Jia, B.C. Low back injury risks during construction with prefabricated (panelised) walls: Effects of task and design factors. Ergonomics 2011, 54, 60-71. [CrossRef] [PubMed]

101. Li, X.M.; Han, S.; Gul, M.; Al-Hussein, M.; El-Rich, M. 3D visualization-based ergonomic risk assessment and work modification framework and its validation for a lifting task. J. Constr. Eng. Manag. 2018, 144. [CrossRef]

102. Yu, Y.T.; Yang, X.C.; Li, H.; Luo, X.C.; Guo, H.L.; Fang, Q. Joint-level vision-based ergonomic assessment tool for construction workers. J. Constr. Eng. Manag. 2019, 145. [CrossRef]

103. Asadi, H.; Yu, D.; Mott, J.H. Risk factors for musculoskeletal injuries in airline maintenance, repair and overhaul. Int. J. Ind. Ergon. 2019, 70, 107-115. [CrossRef]

104. Beyan, A.C.; Alici, N.S.; Cimrin, A. A perspective on occupational musculoskeletal diseases in turkey; case cluster study. J. Clin. Anal. Med. 2017, 8, 117-120. [CrossRef]

105. Chiasson, M.E.; Imbeau, D.; Aubry, K.; Delisle, A. Comparing the results of eight methods used to evaluate risk factors associated with musculoskeletal disorders. Int. J. Ind. Ergon. 2012, 42, 478-488. [CrossRef]

106. Das, B. An evaluation of low back pain among female brick field workers of West Bengal, India. Environ. Health Prev. Med. 2015, 20, 360-368. [CrossRef] [PubMed]

107. Diego-Mas, J.A.; Alcaide-Marzal, J.; Poveda-Bautista, R. Errors using observational methods for ergonomics assessment in real practice. Hum. Factors 2017, 59, 1173-1187. [CrossRef] [PubMed]

108. Dumas, G.A.; Preston, D.; Beaucage-Gauvreau, E.; Lawani, M. Posture analysis of lifting a load for head carriage and comparison between pregnant and non-pregnant women. Work J. Prev. Assess. Rehabil. 2014, 47, 63-72. [CrossRef] [PubMed]

109. Guertler, C.; Speck, G.M.; Mannrich, G.; Merino, G.; Merino, E.A.D.; Seiffert, W.Q. Occupational health and safety management in Oyster culture. Aquac. Eng. 2016, 70, 63-72. [CrossRef]

110. Lamarao, A.M.; Costa, L.C.M.; Comper, M.L.C.; Padula, R.S. Translation, cross-cultural adaptation to Brazilian-Portuguese and reliability analysis of the instrument Rapid Entire Body Assessment-REBA. Braz. J. Phys. Ther. 2014, 18, 211-217. [CrossRef] [PubMed]

111. Mukhopadhyay, P.; Jhodkar, D.; Kumar, P. Ergonomic risk factors in bicycle repairing units at Jabalpur. Work J. Prev. Assess. Rehabil. 2015, 51, 245-254. [CrossRef]

112. Mukhopadhyay, P.; Srivastava, S. Ergonomic design issues in some craft sectors of jaipur. Des. J. 2010, 13, 99-124. [CrossRef]

113. Mukhopadhyay, P.; Srivastava, S. Evaluating ergonomic risk factors in non-regulated stone carving units of Jaipur. Work J. Prev. Assess. Rehabil. 2010, 35, 87-99. [CrossRef]

114. Nam, K.H.; Lee, S.; Kyung, G.; An, J.; An, S. Development of ergonomic gun barrel cleaning method: Automation and its advantages. Hum. Factors Ergon. Manuf. Serv. Ind. 2017, 27, 243-248. [CrossRef]

115. Roman-Liu, D. Comparison of concepts in easy-to-use methods for MSD risk assessment. Appl. Ergon. 2014, 45, 420-427. [CrossRef]

116. Schwartz, A.H.; Albin, T.J.; Gerberich, S.G. Intra-rater and inter-rater reliability of the rapid entire body assessment (REBA) tool. Int. J. Ind. Ergon. 2019, 71, 111-116. [CrossRef]

117. Shanahan, C.J.; Vi, P.; Salas, E.A.; Reider, V.L.; Hochman, L.M.L.; Moore, A.E. A comparison of RULA, REBA and Strain Index to four psychophysical scales in the assessment of non-fixed work. Work J. Prev. Assess. Rehabil. 2013, 45, 367-378. [CrossRef] [PubMed]

118. Motamedzade, M.; Ashuri, M.; Golmohammadi, R.; Mahjub, H. Comparison of ergonomic risk assessment outputs from rapid entire body assessment and quick exposure check in an engine oil company. J. Res. Health Sci. 2011, 11, 26-32. [PubMed] 
119. Gentzler, M.; Stader, S. Posture stress on firefighters and emergency medical technicians (EMTs) associated with repetitive reaching, bending, lifting, and pulling tasks. Work J. Prev. Assess. Rehabil. 2010, 37, 227-239. [CrossRef] [PubMed]

120. Yuan, L. Reducing ergonomic injuries for librarians using a participatory approach. Int. J. Ind. Ergon. 2015, 47, 93-103. [CrossRef]

(C) 2020 by the authors. Licensee MDPI, Basel, Switzerland. This article is an open access article distributed under the terms and conditions of the Creative Commons Attribution (CC BY) license (http://creativecommons.org/licenses/by/4.0/). 